\title{
Racial and Ethnic Diversity: Information Exchange
}

\author{
By Susana Hinojosa \\ Chair, ACRL Racial and Ethnic Diversity Committee
}

Recently established by the ACRL Board of Directors, the ACRL Racial and Ethnic Diversity Committee met for the first time at ALA Midwinter in Chicago. This committee was established upon the strong recommendation from the report of the ACRL Task Force on Recruitment of Underrepresented Minorities. The December 1990 issue of C $\mathcal{R} R L$ News contains the text of the final report of this task force, and the charge to the committee. On behalf of the committee's members and the many librarians who joined our meetings in Chicago, I want to thank the members of the Task Force, especially Dr. Edith Fisher, for their report, thought-provoking recommendations, and for the opportunity to work on these issues.

One recommendation, to develop an information exchange column in ACRL publications, has become a reality. Our goal for the column is to serve as a clearinghouse of information on underrepresented groups and to highlight academic library and ACRL programs, publications, and activities on underrepresented groups in academic libraries. I would appreciate your sending items for the column to: Susana Hinojosa, Moffitt Undergraduate Library, U.C. Berkeley, Berkeley, CA 94720; e-mail: shinojos@library.berkeley.edu; or shinojos@ucblibra.bitnet; fax: (415) 643-7891.

- The ACRL Racial and Ethnic Diversity Committee is developing a survey that will be sent to all ACRL units and chapters, requesting data on the participation of underrepresented librarians as officers and members, information on action plans for increasing participation, and future programs on issues of interest to this committee. Preliminary results will be available by ALA Annual.

- The ALA Recruitment Assembly, composed of representatives from $A L A$ units interested in and working on recruitment to the profession, was formed during ALA Midwinter in Chicago. This group will coordinate recruitment efforts within ALA. Contact: Margaret Myers, ALA OLPR, 50 E. Huron St., Chicago IL 60611 for more information.

- The University of California, Berkeley, School of Library and Information Studies recently formed a Northern California Library Schools Recruitment Committee to promote and encourage the recruitment and mentorship of librarians who reflect the ethnic, cultural, and language diversity of California. The committee's first program, March 2, featured Arabella Martinez, coauthor of the report, "Adrift in a Sea of Change: California's Public Libraries Struggle to Meet the Information Needs of Multicultural Communities." Janice Koyama, 1989 CLA president, responded and related the report to academic libraries. Contact Ana Maria Cobos (Green Library, Stanford University, Stanford, CA 94305-6004) for information about the committee. "Adrift in a Sea of Change" is available from the California State Library Foundation, P.O. Box 942837, Sacramento, CA 94237-0001. Price per report: Californians $\$ 23.30$; and for everyone else $\$ 22.00$ (price includes shipping).

- Fourth Annual National Conference on Racial \& Ethnic Relations in American Higher Education, May 31-June 4, 1991, San Antonio, Texas, “... continues the focus of the series on building multicultural university environments capable of responding to wide-ranging changes occurring throughout society." Contact: The Southwest Center for Human Relations Studies, Univ. of Oklahoma, 555 Constitution, Norman, OK 730370005 , or call (405) 325-3936 for additional information.

- Developing Library Collections for California's Emerging Majority: A Manual of Resources for Ethnic Collection Development is available for $\$ 35$ from: Bay Area Library and Information System (BALIS), 520 3rd St., Suite 202, Oakland, CA 94607-3520; or call (415) 839-6001 for information. The manual focuses on the four major ethnic groups: African American, American Indian, Asian/Southeast Asian, and Chicano/Latino. Intended to help both academic and public libraries develop relevant collections for our increasingly diverse communities, the manual was produced through the joint work and effort of academic and public librarians. 